\title{
Regional overexpression of insulin-like growth factor-I and transforming growth factor- $\beta 1$ in the myocardium of patients with hypertrophic obstructive cardiomyopathy
}

\author{
Guangming Li, MD \\ Michael A. Borger, MD \\ William G. Williams, MD \\ Richard D. Weisel, MD \\ Donald A. G. Mickle, MD \\ E. Douglas Wigle, MD \\ Ren-Ke Li, MD, PhD
}

From the Divisions of Cardiovascular Surgery and Cardiology, Toronto General Hospital and University of Toronto, Toronto, Ontario, Canada.

This research was supported by research grants from the Medical Research Council of Canada (grant No. MOP-14795 and MT10392). R.-K.L. is a Career Investigator of the Heart and Stroke Foundation of Canada

Received for publication Jan 31, 2001; revisions requested March 22, 2001; revisions received June 20, 2001; accepted for publication June 26, 2001

Address for reprints: Ren-Ke Li, MD, $\mathrm{PhD}$, Toronto General Hospital, CCRW 1-815, 200 Elizabeth St, Toronto, Ontario, Canada M5G 2C4 (E-mail: RenKe.Li@uhn.on.ca).

J Thorac Cardiovasc Surg 2002;123:89-95

Copyright (C) 2002 by The American Association for Thoracic Surgery

0022-5223/2002 \$35.00 + $0 \quad \mathbf{1 2 / 1 / 1 1 8 2 7 5}$

doi:10.1067/mtc.2002.118275
Objective: Hypertrophic obstructive cardiomyopathy has been proposed to be the result of gene mutations of contractile proteins. However, we have previously shown significant elevation of insulin-like growth factor-I (IGF-I) and transforming growth factor- $\beta 1$ (TGF- $\beta 1$ ) at the messenger RNA, protein, and receptor levels in patients with hypertrophic obstructive cardiomyopathy when compared with myocardium from patients without this disorder. We hypothesized that this growth factor overexpression is a regional phenomenon. To test this hypothesis, we compared levels of IGF-I and TGF- $\beta 1$ in hypertrophic and nonhypertrophic myocardium within the same group of patients with hypertrophic obstructive cardiomyopathy.

Methods: Two biopsy specimens were obtained from each patient undergoing septal myectomy for severely symptomatic hypertrophic obstructive cardiomyopathy, from hypertrophied septum and from nonhypertrophied myocardium (8 patients in total). Clinical data were prospectively recorded. Messenger RNA levels for growth factor were quantified by means of multiplex reverse transcriptase-polymerase chain reaction, expressed as a densitometric ratio of growth factor/glyceraldehyde-3-phosphate dehydrogenase. Protein levels were quantified by means of chemiluminescent slot blot analysis. Growth factor proteins were used to generate a standard curve.

Results: IGF-I messenger RNA and protein levels in hypertrophic myocardium were 2.6 and 2.9 times greater, respectively, than in nonhypertrophic myocardium of the same patients (both $P<.01$ ). TGF- $\beta 1$ messenger RNA and protein levels in the hypertrophic myocardium were 2.5 and 2.8 times greater, respectively, than the levels in the nonhypertrophied myocardium (both $P<.01$ ). There was a significant correlation between the IGF-I protein ratio (hypertrophic/nonhypertrophic myocardium) and the inducible left ventricular outflow tract gradients measured at cardiac catheterization $(r=0.77, P=.025)$.

Conclusions: Myocardial overexpression of IGF-I and TGF- $\beta 1$ is a regional phenomenon in patients with hypertrophic obstructive cardiomyopathy and is likely involved in the pathogenesis of the disorder.

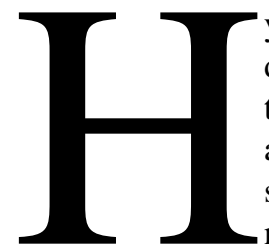

ypertrophic obstructive cardiomyopathy (HOCM) was originally described in the 19th century and was characterized as left ventricular hypertrophy without any apparent cause. HOCM affects approximately 1 in 500 persons and is the most common cause of sudden death in young athletes. ${ }^{1}$ The etiology of this disorder is not known. 
HOCM has a strong familial component and therefore several investigators have focused on a genetic etiology. HOCM is characterized as a heterogeneous disease of the sarcomere, with more than 100 mutations of myocardial contractile protein-encoding areas identified. ${ }^{2}$ Genetic mutations in patients with HOCM have been described in those regions encoding for troponin $T$, troponin $I, \alpha$ tropomyosin, myosin-binding protein $\mathrm{C}$, and the $\beta$-myosin heavy and light chains. However, gene mutations cannot be demonstrated for all patients with this disease, and the precise mechanism by which these mutations lead to hypertrophy is not known. ${ }^{3}$

HOCM is characterized by regional hypertrophy of the interventricular septum, with variable involvement of the remaining myocardium. ${ }^{4}$ Hemodynamic obstruction of the left ventricular outflow tract is often observed. Missense mutations do not fully explain the disparity between the extent of hypertrophy in the septum versus that in the rest of the myocardium in patients with HOCM. We have investigated other potential mechanisms in the pathogenesis of this disorder. 5,6

The role of growth factors in the development of myocardial hypertrophy has received increasing attention in recent years. $^{7-9}$ Insulin-like growth factor-I (IGF-I) ${ }^{10-12}$ and transforming growth factor- $\beta 1$ (TGF- $\beta 1),{ }^{13,14}$ in particular, have been closely linked to cardiomyocyte hypertrophy and excessive production of extracellular matrix. We have previously demonstrated increased levels of IGF-I and TGF- $\beta 1$ and normal levels of IGF-II and platelet-derived growth factor-B in hypertrophied septum of patients with HOCM when compared with patients without HOCM.,6 Protein, messenger RNA, and receptor levels for IGF-I and TGF- $\beta 1$ were increased in the hypertrophic HOCM myocardium when compared with the hypertrophied septum of patients with aortic stenosis, as well as with biopsy specimens from the left ventricular free wall of patients with aortic stenosis, stable angina, and dilated cardiomyopathy. Regional differences in patients without HOCM were not found.

Our findings of elevated growth factor levels in patients with HOCM were surprising because the long-standing hypertrophy of our patients with aortic stenosis was not mediated by increased myocardial IGF-I and TGF- $\beta 1$ levels. Also, animal models of myocardial hypertrophy induced by pressure overload resulted in a transient increase in left ventricular IGF-I protein and mRNA levels, ${ }^{15,16}$ with levels returning to baseline within 6 weeks despite ongoing hypertension and increasing ventricular hypertrophy. Because the nonhypertrophied HOCM myocardium was exposed to the same intraventricular pressures as the hypertrophied HOCM myocardium, we hypothesized that excess production of growth factors must be a localized phenomenon. We also hypothesized that this regional overexpression would lead to regional hypertrophy through a paracrine or autocrine mechanism. If IGF-I and TGF- $\beta 1$ protein and mRNA levels in nonhypertrophied HOCM myocardium were similar to the levels found in the myocardium of patients with stable angina, aortic stenosis, and cardiomyopathy, the increased levels measured in the hypertrophied region of the HOCM myocardium would be a localized autonomous response and not a generalized systemic disease process. To test this hypothesis, we compared growth factor protein levels, mRNA levels, and receptor levels in hypertrophied septum to nonhypertrophied left ventricular myocardium in 8 consecutive patients undergoing myectomy for HOCM.

\section{Methods}

\section{Myocardial Biopsies and Operative Methods}

Biopsy samples were obtained from the resected hypertrophied septum and from the nonhypertrophied left ventricular apex in 8 consecutive patients undergoing septal myectomy for severely symptomatic HOCM. The hypertrophic region was localized by intraoperative transesophageal echocardiography and visual inspection. Each biopsy specimen was immediately frozen by, and temporarily stored in, liquid nitrogen. All patients underwent a septal myectomy and none required mitral valve replacement, as previously described. ${ }^{17}$ All patients gave written informed consent for biopsy tissue to be obtained through a protocol approved by the Toronto General Hospital Human Experimentation Committee.

\section{Evaluation of Growth Factor mRNA Levels}

Myocardial biopsy specimens (7-20 mg) were homogenized in 1 $\mathrm{mL}$ of TRIzol (GIBCO BRL, Life Technologies, Inc, Burlington, Canada) and then incubated on ice for 10 minutes. Chloroform $(300 \mu \mathrm{L})$ was added and the mixture was treated in a vortex for 15 seconds. The mixture was centrifuged at $14,000 \mathrm{~g}$ for 10 minutes. Then $2 \mu \mathrm{L}$ of DNase (Amersham Pharmacia Biotech, Piscataway, $\mathrm{NJ})$ was added to the supernatant and incubated at $37^{\circ} \mathrm{C}$ for 15 minutes. Isopropanol $(500 \mu \mathrm{L})$ was added and the solution was incubated at $-70^{\circ} \mathrm{C}$ for 60 minutes. Centrifugation ( 15 minutes at $14,000 \mathrm{~g}$ ) was repeated and the pellet was dissolved in diethyl pyrocarbonate water. Total RNA concentration for each sample was quantified spectrophotometrically.

Total RNA (10 $\mu \mathrm{g} / \mathrm{sample})$ was combined with 20 units of Moloney murine leukemia virus reverse transcriptase (GIBCO BRL, Life Technologies), $4 \mu \mathrm{L}$ of $5 \times$ reverse transcriptase reaction buffer, $1 \mu \mathrm{L}$ of $25 \mathrm{mmol} / \mathrm{L}$ deoxyribonucleoside triphosphatase, $2 \mu \mathrm{L}$ of $0.1 \mathrm{~mol} / \mathrm{L}$ dithiothreitol, $1 \mu \mathrm{L}$ of $150 \mu \mathrm{mol} / \mathrm{L}$ oligo deoxythymidine (20 oligomer), $1 \mu \mathrm{L}$ of RNAse inhibitor, and sterilized water to bring the total reaction volume to $20 \mu \mathrm{L}$. After incubation at $37^{\circ} \mathrm{C}$ for 60 minutes, the reaction was stopped and the RNA was denatured with the addition of $30 \mu \mathrm{L}$ of 0.7 $\mathrm{mol} / \mathrm{L} \mathrm{NaOH} / 45 \mathrm{mmol} / \mathrm{L}$ ethylenediaminetetraacetic acid. Singlestranded complementary DNA was precipitated, resuspended in water, and stored at $-20^{\circ} \mathrm{C}$.

Multiplex reverse transcriptase-polymerase chain reaction (RTPCR) was used for quantitative analysis of growth factor mRNAs, with glyceraldehyde-3-phosphate dehydrogenase (GAPDH) used as the internal control. The specific human primer sequences and 
TABLE 1. PCR primer sequences of growth factor genes

\begin{tabular}{|c|c|c|}
\hline $\begin{array}{l}\text { cDNA and } \\
\text { primer }\end{array}$ & Sequence of primer & Product size \\
\hline \multicolumn{3}{|l|}{ GAPDH } \\
\hline Forward & 5'-TGAAGGTCGGAGTCAACGGATTTGGT-3' & 983 bp \\
\hline $\begin{array}{l}\text { Reverse } \\
\text { IGF-I }\end{array}$ & 5'-CATGTGGGCCATGAGGTCCACCAC-3' & \\
\hline Forward & 5'-TCTTCAGTTCGTGTGTGGAGAC-3' & $180 \mathrm{bp}$ \\
\hline Reverse & 5'ACAGAGCGAGCTGACTTGGC-3' & \\
\hline \multicolumn{3}{|l|}{ TGF- $\beta 1$} \\
\hline Forward & 5'-ACCATTCATGGCATGAACCGG-3' & $411 \mathrm{bp}$ \\
\hline Reverse & 5'AGCGCACGATCATGTTGGACA-3' & \\
\hline
\end{tabular}

$P C R$, Polymerase chain reaction; GAPDH, glyceraldehyde-3-phosphate dehydrogenase; $b p$, base pair; IGF-I, insulin-like growth factor-I; TGF- $\beta 1$, transforming growth factor- $\beta 1$.

their sizes are summarized in Table 1 . The PCR (total volume 100 $\mu \mathrm{L}$ ) contained $10 \mu \mathrm{L}$ of $10 \times$ PCR buffer, $3 \mu \mathrm{L}$ of $50 \mathrm{mmol} / \mathrm{L}$ $\mathrm{MgCl}_{2}, 1 \mu \mathrm{L}$ each of $15 \mathrm{pmol}$ GAPDH, IGF-I, or TGF- $\beta 1$ forward and reverse primer, $10 \mu \mathrm{L}$ (100 ng) of single-stranded cDNA, $1 \mu \mathrm{L}$ of $25 \mathrm{mmol} / \mathrm{L}$ deoxyribonucleoside triphosphatase, $2.5 \mathrm{U}$ of Taq DNA polymerase, and sterile water. The samples were directly transferred from ice to the thermal cycler (Perkin-Elmer Cetus; Technical Lab Services, Toronto, Ontario, Canada), and 30 reaction cycles were performed. The PCR products were run on a $1 \%$ agarose gel, and the relative density of GAPDH and growth factor bands were determined with a computerized densitometry system (Bio-Rad Gel Doc 1000; Bio-Rad Laboratories, Inc, Mississauga, Canada). After gel analysis, the PCR products of specific growth factors were extracted from the gel.

\section{Evaluation of Protein and Receptor Levels for Growth Factor}

$\mathrm{We}^{5}$ have previously described our method of quantifying protein levels for growth factor. Myocardial tissue was homogenized in 50 $\mathrm{mmol} / \mathrm{L}$ Tris- $\mathrm{HCl}(\mathrm{pH} 7.4)$, then centrifuged at $14,000 \mathrm{~g}$ for 15 minutes at $4^{\circ} \mathrm{C}$. Supernatant protein concentration was measured by Bio-Rad protein assay. Myocardial protein, $10 \mu \mathrm{g}$, along with serial concentrations of IGF-I and TGF- $\beta 1$ standards (Sigma Chemical Co, St Louis, Mo), were separately loaded onto a polyvinylidene fluoxide microporous membrane with the use of the Minifold II Slot Blotting System (Schleicher \& Schuell, Dassel, Germany). The membrane was dried and washed twice with TBS-T buffer $(50 \mathrm{mmol} / \mathrm{L}$ Tris- $\mathrm{HCl}$ buffer and $0.1 \%$ Tween20) for 10 minutes and treated with blocking buffer (BoehringerMannheim, Mannheim, Germany) for 60 minutes. Monoclonal antibodies against IGF-I and TGF- $\beta 1$ and their receptors (Cedarlane Laboratories, Ltd, Hornby, Ontario, Canada) (1: 3000, diluted with $0.5 \times$ blocking buffer) were added and incubated overnight at $4^{\circ} \mathrm{C}$. The membrane was washed twice with TBS-T and then incubated with goat anti-mouse horseradish peroxidaseconjugated antibody (1:3000 dilution) (Bio-Rad) for 60 minutes at room temperature. After being washed twice with TBS-T, IGF-I and TGF- $\beta 1$ protein levels were detected by chemiluminescence (Boehringer-Mannheim). Densitometric analyses of the standards
TABLE 2. Clinical data of patients with HOCM undergoing septal myectomy $(n=8)$

\begin{tabular}{lc}
\hline Characteristic & \\
\hline Male sex, No. (\%) & $6(75.0)$ \\
Age (y) & $53.4 \pm 12.5$ \\
Risk factors, No. (\%) & \\
$\quad$ Syncope & $3(37.5)$ \\
Atrial fibrillation & $2(25.0)$ \\
$\quad$ Ventricular tachycardia & $1(12.5)$ \\
Family history & $4(50.0)$ \\
Medications, No. (\%) & \\
$\quad \beta$-Blockers & $4(50.0)$ \\
Disopyramide & $4(50.0)$ \\
Calcium channel blockers & $0(0)$ \\
Antiarrhythmic drugs & $2(25.0)$ \\
NYHA class & $3.1 \pm 0.4$ \\
CCS class & $2.9 \pm 0.6$ \\
LVOT obstruction (mm Hg) & \\
$\quad$ At rest & $56.6 \pm 28.3$ \\
Inducible & $131.3 \pm 51.9$ \\
Maximum septal thickness (mm) & $21 \pm 2.5$ \\
Mitral regurgitation (moderate or severe), No. (\%) & $6(75.0)$ \\
Coronary artery disease, No. (\%) & $0(0)$
\end{tabular}

Plus-minus values are means \pm SD. NYHA, New York Heart Association heart failure classification; CCS, Canadian Cardiovascular Society angina classification; $L V O T$, left ventricular outflow tract.

and sample bands were performed with a Bio-Rad image analysis system expressed as nanograms per gram of tissue.

\section{Statistical Analysis}

All values are expressed as mean $\pm \mathrm{SD}$, with the exception of categorical variables, which are expressed as percentages. Comparison of protein, mRNA, and receptor levels of growth factor in hypertrophied and nonhypertrophied myocardium were performed with paired $t$ tests. Correlation between growth factor levels and septal thickness and pressure gradient measurements were assessed with Pearson product-moment coefficients.

\section{Results}

The preoperative clinical features of our patient population are displayed in Table 2. All patients had severe symptoms refractory to medical therapy. In addition, all patients had marked septal hypertrophy and large left ventricular outflow tract gradients. Mitral regurgitation, associated with severe systolic anterior motion, was mild in 2 patients, moderate in 2 patients, and severe in 4 patients.

Perioperatively, all patients did well with the exception of 1 patient who had a left hemispheric cerebral infarct 4 days after the operation. This patient continues to have a mild hemiparesis. There were no other complications or deaths. 


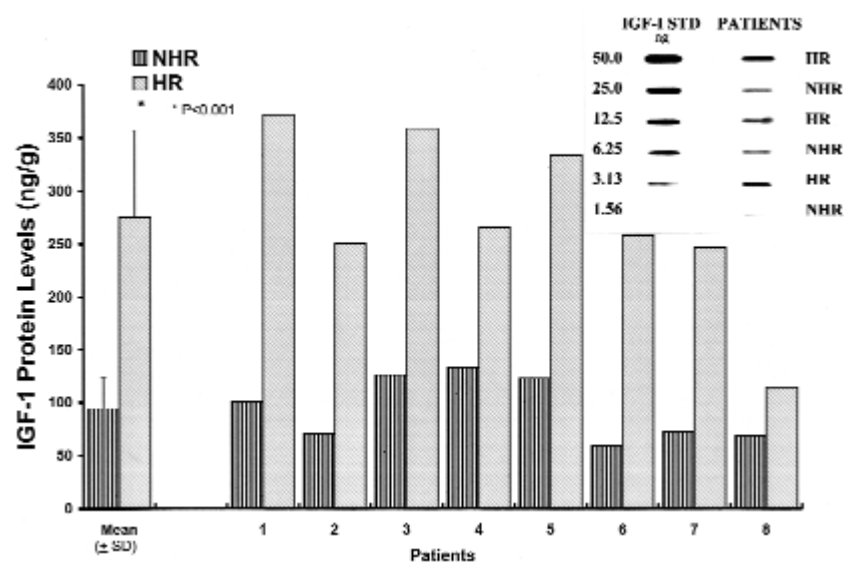

Figure 1. IGF-I protein levels in hypertrophied (HR) and nonhypertrophied (NHR) myocardium obtained from 8 patients with idiopathic HOCM were quantified with a slot blot analysis (inset). IGF-I was used as the protein standard (STD). IGF-I levels were significantly $(P<.001)$ higher in hypertrophied regions. IGF-I protein levels in the HR and NHR myocardium of 3 randomly selected patients are shown in the inset beside the IGF-I protein standards.

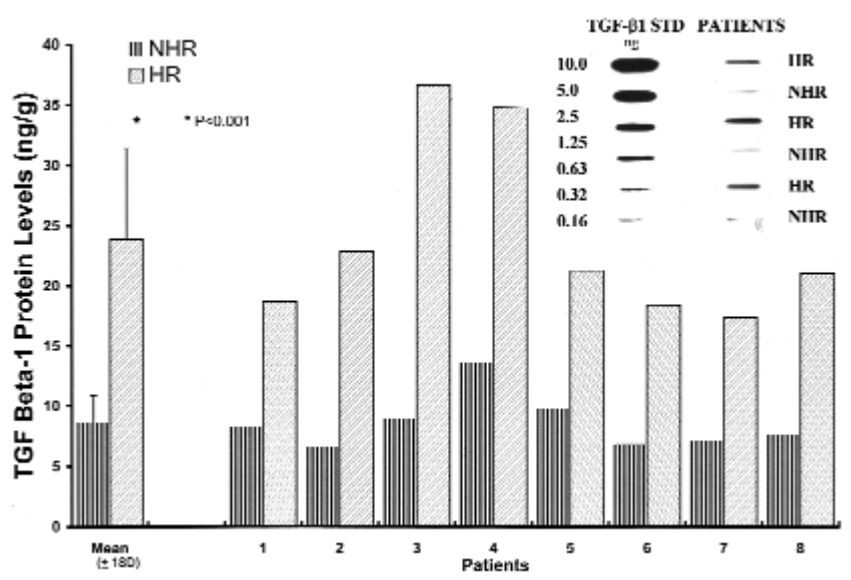

Figure 2. TGF- $\beta 1$ protein levels in hypertrophied (HR) and nonhypertrophied myocardium (NHR) obtained from 8 patients with idiopathic HOCM were quantified with a slot blot analysis (inset). TGF- $\beta 1$ was used as the protein standard (STD). TGF- $\beta 1$ levels were significantly $(P<.001)$ higher in hypertrophied regions. TGF$\beta 1$ protein levels in the HR and NHR myocardium of 3 randomly selected patients are shown in the inset beside the TGF- $\beta 1$ protein standards.

Three months postoperatively, symptoms had markedly improved. The mean New York Heart Association heart failure class decreased to $1.8 \pm 0.5$ from $3.1 \pm 0.4$ preoperatively $(P=.001)$, and the mean Canadian Cardiovascular Society angina class decreased to $1.3 \pm 0.5$ from $2.9 \pm 0.6(P<.001)$. Left ventricular outflow tract gradients also significantly improved, with a mean gradient of $7.0 \pm 2.8 \mathrm{~mm} \mathrm{Hg}$ at rest

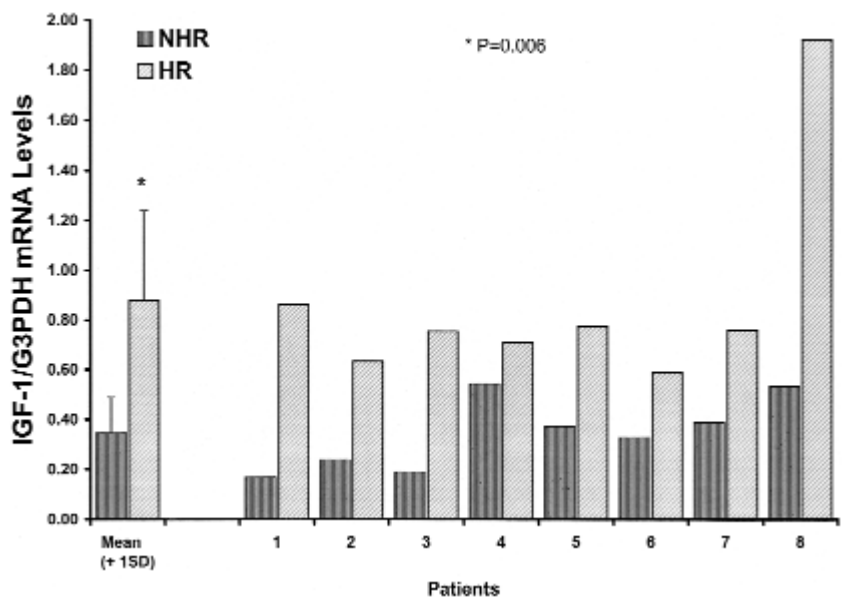

Figure 3. IGF-I mRNA levels, expressed as a ratio to glyceraldehyde-3-phosphate dehydrogenase (G3PDH) in hypertrophied (HR) and nonhypertrophied myocardium (NHR) obtained from 8 patients with idiopathic HOCM. IGF-I gene expression was significantly ( $P$ $<.01)$ higher in the hypertrophied regions.

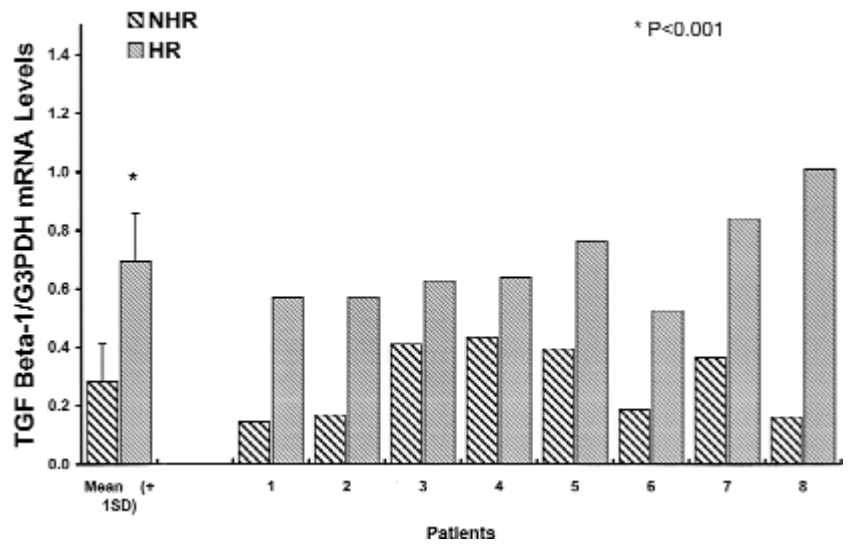

Figure 4. TGF- $\beta 1$ mRNA levels in hypertrophied (HR) and nonhypertrophied myocardium (NHR) obtained from 8 patients with idiopathic HOCM. TGF- $\beta 1$ gene expression was significantly $(p<.001)$ higher in the hypertrophied regions. G3PDH, Glyceraldehyde-3phosphate dehydrogenase.

(vs $56.6 \pm 28.3 \mathrm{~mm} \mathrm{Hg}$ before the operation) and $14.4 \pm 8.0$ $\mathrm{mm} \mathrm{Hg}$ after exercise (vs $131.3 \pm 51.9 \mathrm{~mm} \mathrm{Hg}$ before the operation; both $P<.001$ ). None of the patients had mitral regurgitation at the time of postoperative follow-up.

Figure 1 displays IGF-I protein levels from the hypertrophied septum and from the nonhypertrophied myocardium for all 8 patients. IGF-I protein levels were significantly $(P$ $<.001)$ higher in hypertrophied areas than in apical myocardium ( $275.2 \pm 82.2$ vs $94 \pm 30 \mathrm{ng} / \mathrm{g}$ of tissue). The mean IGF-I protein ratio (hypertrophied/nonhypertrophied myocardium) was $3.1 \pm 0.9$. TGF- $\beta 1$ protein levels were 
also significantly higher $(P<.001)$ in hypertrophied areas than in nonhypertrophic regions $(23.9 \pm 7.5$ vs $8.6 \pm 2.3$ $\mathrm{ng} / \mathrm{g}$ of tissue, Figure 2). The mean TGF- $\beta 1$ protein ratio was $2.8 \pm 0.7$. Growth factor mRNA levels, expressed as a ratio to GAPDH, are displayed in Figures 3 and 4. The IGFI mRNA levels in hypertrophic myocardium were significantly higher than in nonhypertrophic regions $(0.88 \pm 0.43$ vs $0.34 \pm 0.14$, respectively; $P<.01)$. TGF- $\beta 1$ mRNA levels were also significantly $(P<.001)$ elevated in the hypertrophied myocardium $(0.69 \pm 0.17$ vs $0.28 \pm 0.13$ for nonhypertrophic myocardium). The IGF-I and TGF- $\beta 1$ protein and mRNA levels in the nonhypertrophic HOCM myocardium were similar to the levels we previously found in stable angina, aortic stenosis, and explanted ischemic cardiomyopathic hearts. ${ }^{5,6}$

We were able to measure growth factor receptor levels in 5 of 8 patients. The amount of protein was not sufficient in the remaining 3 patients. A statistically nonsignificant trend toward higher growth factor receptor levels was observed in hypertrophied areas for both IGF-I (mean ratio $1.9 \pm 0.5 ; P$ $=.10$ ) and TGF- $\beta 1$ (mean ratio $1.8 \pm 0.4 ; P=.08$ ).

We performed correlation analyses between ratios of growth factor protein levels (hypertrophied/nonhypertrophied myocardium) and clinical measurements of septal hypertrophy. Pressure gradients (millimeters of mercury) were measured at the time of cardiac catheterization at rest and after induction with amyl nitrite. Maximum septal thickness (millimeters) was recorded during intraoperative transesophageal echocardiography. A good clinical correlation existed between IGF-I protein ratios and inducible left ventricular outflow tract gradients $(r=0.77, P=.025)$. The correlation between TGF- $\beta 1$ and clinical indices of hypertrophy was poor.

\section{Discussion}

HOCM may be inherited as a mendelian dominant characteristic with variable penetrance and diverse phenotypic expression. ${ }^{4}$ Regional hypertrophy with left ventricular outflow tract obstruction is a consistent characteristic. Although many sarcomeric protein-encoding mutations have been identified, ${ }^{3}$ these mutations do not account for the regional disparity in myocardial hypertrophy that is observed in patients with HOCM. We postulated that localized overexpression of growth factors may be involved in the pathogenesis of this regional hypertrophy.

Several investigators have studied the association between growth factors and myocardial hypertrophy. ${ }^{9}$ IGF-I has been demonstrated to stimulate in culture cardiomyocyte hypertrophy in the absence of mechanical loading by increasing gene expression, protein synthesis, and protein accumulation. ${ }^{11,13}$ Duerr and associates demonstrated hypertrophy of normal rat hearts in vivo after administration of IGF-I, ${ }^{10}$ as well as hypertrophy and improved ventricular function after myocardial infarction. ${ }^{18}$ Delaughter and colleagues ${ }^{19}$ used a transgenic mouse model to demonstrate that persistent expression of IGF-I leads to physiologic and then pathologic cardiac hypertrophy. Butt and Bishop ${ }^{20}$ reported that IGF-I acts synergistically with mechanical loading to increase procollagen gene expression and metabolism in cardiac fibroblasts. Animal models of myocardial hypertrophy induced by pressure overload result in a transient increase in left ventricular IGF-I protein and mRNA levels. ${ }^{15,16}$ Although the increase in ventricular IGF-I levels occurred with the onset of hypertension and hypertrophy, the IGF-I levels returned to control levels within 6 weeks despite the continued presence of hypertension and increasing ventricular hypertrophy. The authors suggest that the transient increase in myocardial IGF-I was necessary only to initiate myocardial hypertrophy. Other investigators have demonstrated that antihypertensive treatment of hypertensive rats results in a significant reduction of previously elevated myocardial IGF-I mRNA and protein levels..$^{21,22}$

Clinical studies have revealed a strong correlation between circulating IGF-I levels and left ventricular mass in patients with systemic hypertension. ${ }^{23}$ Postmortem $^{12}$ and aorta-coronary sinus ${ }^{24}$ studies have demonstrated significantly higher myocardial IGF-I protein levels in patients with left ventricular hypertrophy than in controls.

Several investigators have also demonstrated a relationship between TGF- $\beta 1$ and myocardial hypertrophy, although to a lesser degree than IGF-I. Villarreal and Dillmann ${ }^{14}$ demonstrated that TGF- $\beta 1$ gene expression is transiently increased in hypertrophied myocardium. Butt and Bishop ${ }^{20}$ reported that the addition of TGF- $\beta 1$ to pressure-loaded cardiac fibroblasts increases procollagen synthesis. Decker and colleagues ${ }^{13}$ demonstrated that TGF- $\beta 1$ enhances cardiomyocyte protein and myosin heavy chain synthesis in the absence of mechanical loading, although to a lesser extent than IGF-I.

We previously reported growth factor levels in patients with HOCM compared with patients with pressure-induced myocardial hypertrophy or no hypertrophy. We analyzed IGF-I, IGF-II, TGF- $\beta 1$, and platelet-derived growth factorB mRNA levels in resected hypertrophic septal specimens of patients with HOCM and compared them with the myocardium of patients with aortic stenosis, stable angina, and ischemic cardiomyopathy. ${ }^{6}$ Hypertrophied myocardium from patients with HOCM had significantly higher levels of IGF-I and TGF- $\beta 1$ gene expression than all other patient groups. The mRNA levels for myocardial IGF-II and platelet-derived growth factor-B did not differ among the patient groups studied. Further studies revealed elevated protein levels of IGF-I and TGF- $\beta 1$, as well as increased growth factor receptor binding site activity, in hypertrophic specimens from patients with HOCM when compared with other patient populations. ${ }^{5}$ In addition, we ${ }^{5}$ identified the 
cardiomyocyte as the major site of IGF-I receptors and the fibroblast as the major site of TGF- $\beta 1$ receptors. It is of particular interest that IGF-I and TGF- $\beta 1$ levels from hypertrophied myocardium of patients with HOCM were significantly higher (3- and 2-fold, respectively) than in patients with load-induced hypertrophy, that is, aortic stenosis. This finding suggests that the localized increase in growth factor levels in HOCM myocardium was not simply a consequence of hypertension. In addition, IGF-I and TGF$\beta 1$ protein, mRNA, and receptor levels in the left ventricular free wall of patients with stable angina and in the endocardial septum of patients with aortic stenosis were similar and did not differ from levels found in the nonhypertrophic apical myocardium of patients with HOCM. It should be stressed that in our previous studies, hypertrophic and nonhypertrophic myocardial biopsy specimens were compared between different patients with HOCM. In the current study, apical and septal specimens were obtained from the same patients.

The current study was performed to compare hypertrophied septum and nonhypertrophied apical myocardium in patients undergoing subaortic myectomy for HOCM. Comparisons were made within patients to determine whether the elevated growth factor levels for IGF-I and TGF$\beta 1$ were a regional phenomenon. We demonstrated significantly increased IGF-I and TGF- $\beta 1$ protein levels and gene expression and a nonsignificant increase in receptor levels only in the hypertrophied regions compared with the nonhypertrophied myocardium. In addition, we found fair to good correlation between IGF-I protein level and left ventricular outflow tract gradients and septal thickness, important clinical parameters in the evaluation of degree of hypertrophy. ${ }^{17}$

Fujiwara and associates ${ }^{25}$ and Tanaka, Fujiwara, and Kawai ${ }^{26}$ have shown that the number and size of myocytes are significantly increased in the hypertrophic region when compared with the nonhypertrophic region of the left ventricle in patients with HOCM. The increased number of hypertrophied cardiomyocytes implies an embryonic origin of this disease process, which in turn is consistent with HOCM being a cause of stillbirths and the development of HOCM during infancy. Since myocardial hypertrophy is frequently seen in the late teens and early twenties of patients with HOCM, we speculate that young patients with HOCM will have higher hypertrophic myocardial levels of IGF-I and TGF - $\beta 1$ than adult patients. Consistent with this hypothesis is the finding that cardiomyopathy develops early as a result of cardiomyocyte hyperplasia in transgenic mice that overexpress myocardial IGF-I. ${ }^{27}$ We believe the regulation of IGF-I is abnormally increased because of the loss of feedback regulation in the HOCM disease process.

The mechanism that causes localized increases in growth factors in patients with HOCM is not known. The regional elevations in IGF-I and TGF- $\beta 1$ growth factor, mRNA, and receptor levels cannot be explained by the intraventricular hypertension alone, because nonhypertrophic myocardium is exposed to the same pressures. Furthermore, many patients with HOCM have asymmetric hypertrophy before intraventricular pressures are elevated. As we previously reported, the IGF-I and TGF- $\beta 1$ growth factor, mRNA, and receptor elevations in the globally hypertrophic myocardium of patients with severe aortic stenosis were 2- to 3-fold less than levels in hypertrophic myocardium of patients with HOCM. We believe the growth factor increase is autonomous and causes the hypertrophy through an autocrine or paracrine phenomenon. ${ }^{5}$ Alternatively, the elevation in growth factors may be a compensatory response to contractile protein mutations or an unknown factor. However, it is unclear why either of these possible mechanisms would be localized to the septum.

Further studies are required of growth factor-associated hypertrophy in HOCM. In particular, the mechanisms of IGF-I and TGF- $\beta 1$ regulation, the relationship between growth factors and gene mutations, and the possibility of prevention or reversal of growth factor-associated hypertrophy by means of antisense DNA therapy need to be analyzed. If therapeutic studies are successful in an animal model, localized treatment may be possible in patients with HOCM. By means of interventional technology similar to that used for percutaneous alcohol septal ablation, ${ }^{28}$ adenovirus $^{29}$ with growth factor antisense DNA with a tetracycline-activated promotor could be delivered directly to the hypertrophied myocardium in high-risk patients or in patients considered for surgical correction.

In conclusion, we found localized elevations of protein and mRNA levels for IGF-I and TGF- $\beta 1$ in hypertrophied septal myectomy specimens of patients with HOCM. Elevated growth factor levels present a potentially novel mechanism to explain the regionalized hypertrophy present in patients with HOCM. Further studies need to be performed to determine whether growth factor-targeted therapy is a possibility for this important clinical disease.

\section{References}

1. Maron BJ. Hypertrophic cardiomyopathy. Lancet. 1997;350:127-33.

2. Niimura H, Bachinski LL, Sangwatanaroj, Watkins H, Chudley AE, McKenna W, et al. Mutations in the gene for cardiac myosin-binding protein $\mathrm{C}$ and late-onset familial hypertrophic cardiomyopathy. $\mathrm{N}$ Engl J Med. 1998;338:1248-57.

3. St John Sutton M, Epstein JA. Hypertrophic cardiomyopathybeyond the sarcomere. N Engl J Med. 1998;338:1303-4.

4. Wigle ED, Rakowski H, Kimball BP, Williams WG. Hypertrophic cardiomyopathy: clinical spectrum and treatment. Circulation. 1995;97: 1680-92.

5. Li G, Li R-K, Mickle DAG, Merante F, Ball WT, Christakis GT, et al. Elevated insulin-like growth factor-I and transforming growth factor$\beta 1$ and their receptors in patients with idiopathic hypertrophic obstructive cardiomyopathy: a possible mechanism. Circulation. 1998;98(Suppl):II144-9.

6. Li R-K, Li G, Mickle DAG, Merante F, Luss H, Rao V, et al. 
Overexpression of transforming growth factor- $\beta 1$ and insulin-like growth factor-I in patients with idiopathic hypertrophic cardiomyopathy. Circulation. 1997;96:874-81.

7. Sadoshima J, Izumo S. The cellular and molecular response of cardiac myocytes to mechanical stress. Annu Rev Physiol. 1997;59:551-71.

8. Lembo G, Hunter JJ, Chien KR. Signaling pathways for cardiac growth and hypertrophy: recent advances and prospects for growth factor therapy. Ann N Y Acad Sci. 1995;752:115-27.

9. Hunter JJ, Chien KR. Signaling pathways for cardiac hypertrophy and failure. N Engl J Med. 1999;341:1276-83.

10. Duerr RL, Huang S, Miraliakbar HR, Clark R, Chien KR, Ross J Jr. Insulin-like growth factor-1 enhances ventricular hypertrophy and function during the onset of experimental cardiac failure. $J$ Clin Invest. 1995;95:619-27.

11. Ito H, Hiroe M, Hirata $Y$, Tsujino M, Adachi S, Shichiri M, et al. Insulin-like growth factor-1 induces hypertrophy with enhanced expression of muscle-specific genes in cultured rat cardiomyocytes. Circulation. 1993;87:1715-21.

12. Pauliks LB, Cole KE, Mergner WJ. Increased insulin-like growth factor-1 protein in human left ventricular hypertrophy. Exp Mol Pathol. 1999;66:53-8

13. Decker RS, Cook MG, Behnke-Barclay M, Decker ML. Some growth factors stimulate cultured adult rabbit ventricular myocyte hypertrophy in the absence of mechanical loading. Circ Res. 1995;77:544-55.

14. Villarreal FJ, Dillmann WH. Cardiac hypertrophy-induced changes in mRNA levels for TGF-beta 1, fibronectin, and collagen. Am J Physiol. 1992;262:H1861-6.

15. Donohue TJ, Dworkin LD, Lango MN, Fliegner K, Lango RP, Benstein JA, et al. Induction of myocardial insulin-like growth factor1 gene expression in left ventricular hypertrophy. Circulation. 1994; 89:799-809.

16. Ebensperger R, Acevedo E, Melendez J, Corbalan R, Acevedo M, Sapag-Hagar M, et al. Selective increase in IGF-I in a rat model of ventricular hypertrophy. Biochem Biophys Res Commun. 1998;243:20-4.

17. Williams WG, Ralph-Edwards AC, Wigle ED. Surgical management of hypertrophic obstructive cardiomyopathy. Cardiol Rev. 1997;5:40-9.

18. Duerr RL, McKirnan D, Gim RD, Clark RG, Chien KR, Ross J Jr. Cardiovascular effects of insulin-like growth factor- 1 and growth hormone in chronic left ventricular failure in the rat. Circulation. 1996; 93:2188-96.
19. Delaughter MC, Tagget GE, Fiorotto ML, Entman ML, Schwartz RJ. Local insulin-like growth factor I expression induces physiologic, then pathologic, cardiac hypertrophy in transgenic mice. FASEB $J$. 1999;13:1923-9.

20. Butt RP, Bishop JE. Mechanical load enhances the stimulatory effect of serum growth factors on cardiac fibroblast procollagen synthesis. $J$ Mol Cell Cardiol. 1997;29:1141-51.

21. Jalil JE, Ebensperger R, Melendez J, Acevedo E, Sapag-Hagar M, Gonzalez-Jara F, et al. Effects of antihypertensive treatment on cardiac IGF-I during prevention of ventricular hypertrophy in the rat. Life Sci. 1999;64:1603-12.

22. Donohue TJ, Dworkin LD, Ma J, Lango MN, Catanese VM. Antihypertensive agents that limit ventricular hypertrophy inhibit cardiac expression of insulin-like growth factor-I. J Investig Med. 1997;45:584-91

23. Diez J, Laviades C. Insulin-like growth factor-1 and cardiac mass in essential hypertension: comparative effects of captopril, lisinopril and quinapril. J Hypertens. 1994;12:s31-6.

24. Serneri GG, Modesti PA, Boddi M, Cecioni I, Paniccia R, Coppo M, et al. Cardiac growth factors in human hypertrophy. Relations with myocardial contractility and wall stress. Circ Res. 1999;85:57-67.

25. Fujiwara H, Hoshino T, Yamana K, Fujiwara T, Furuta M, Hamashima $\mathrm{Y}$, et al. Number and size of myocytes and amount of interstitial space in the ventricular septum and in the left ventricular free wall in hypertrophic cardiomyopathy. Am J Cardiol. 1983;52:818-23.

26. Tanaka M, Fujiwara H, Kawai C. Pathological features of hypertrophic cardiomyopathy without asymmetrical septal hypertrophy. $\mathrm{Br}$ Heart J. 1986;56:294-7.

27. Reiss K, Cheng W, Ferber A, Kajstura J, Li P, Li B, et al. Overexpression of insulin-like growth factor-1 in the heart is coupled with myocyte proliferation in transgenic mice. Proc Natl Acad Sci U S A. 1996;93:8630-5

28. Knight C, Kurbaan AS, Seggewiss H, Henein M, Gunning M, Harrington D, et al. Nonsurgical septal reduction for hypertrophic obstructive cardiomyopathy: outcome in the first series of patients. Circulation. 1997;95:2075-81.

29. Villarreal DJ, Lee AA, Dillmann WH, Giordano FJ. Adenovirus-mediated overexpression of human transforming growth factor-beta 1 in rat cardiac fibroblasts, myocytes and smooth muscle cells. J Mol Cell Cardiol. 1996;28:735-42. 